\title{
Soil physicochemical properties drive the variation in soil microbial communities along a forest successional series in a degraded wetland in northeastern China
}

\author{
Xin Sui ${ }^{1}$, Rong Zhang ${ }^{2}$, Beat Frey ${ }^{3}, \mathrm{Nan} \mathrm{Xu}^{2}$, Hongwei $\mathrm{Ni}^{4}$, and Maihe $\mathrm{Li}^{5}$ \\ ${ }^{1}$ Heilongjiang Academy of Sciences Institute of Natural Resources and Ecology \\ ${ }^{2}$ Affiliation not available \\ ${ }^{3}$ Swiss Federal Research Institute WSL, 8903 Birmensdorf, Switzerland \\ ${ }^{4}$ Heilongjiang Academy of Sciences \\ ${ }^{5}$ Swiss Federal Research Institute WSL
}

May 5, 2020

\begin{abstract}
The Sanjiang Plain is the biggest freshwater wetland locating within northeastern China. Due to climate change and human activities, that wetland has degraded to a successional gradient from the original flooded wetland to dry shrub vegetation and a forest area with lower ground water level, resulting in changes in soil microbiologic structure and functions. The present study investigated the microbial diversity and community structure in relation to soil properties along this gradient. The soil physic-chemical properties changed significantly with degradation. The Shannon variety of soil fungi as well as bacteria varied significantly with successional stage (both $\mathrm{P}<0.05$ ). The community structures of soil bacteria and fungi in the early successional stages (i.e., the wetland) were significantly structured via total phosphorus, available nitrogen and total nitrogen concentrations in soils, while those in the later successional stages (i.e., forests) were significantly structured by soil organic carbon, soil pH and available phosphorus concentrations. Our results indicated that variations in the soil environment affected soil microbial communities along a successional gradient from wetland to forests are mainly. These outcomes indicate that above ground plant composition is a forceful determinant of the structure as well as functions of bacterial and fungal communities, might finally causing substantial alterations in ecosystem activity.
\end{abstract}

\section{Hosted file}

MS2003.doc available at https://authorea.com/users/301675/articles/431514-soilphysicochemical-properties-drive-the-variation-in-soil-microbial-communities-along-aforest-successional-series-in-a-degraded-wetland-in-northeastern-china 

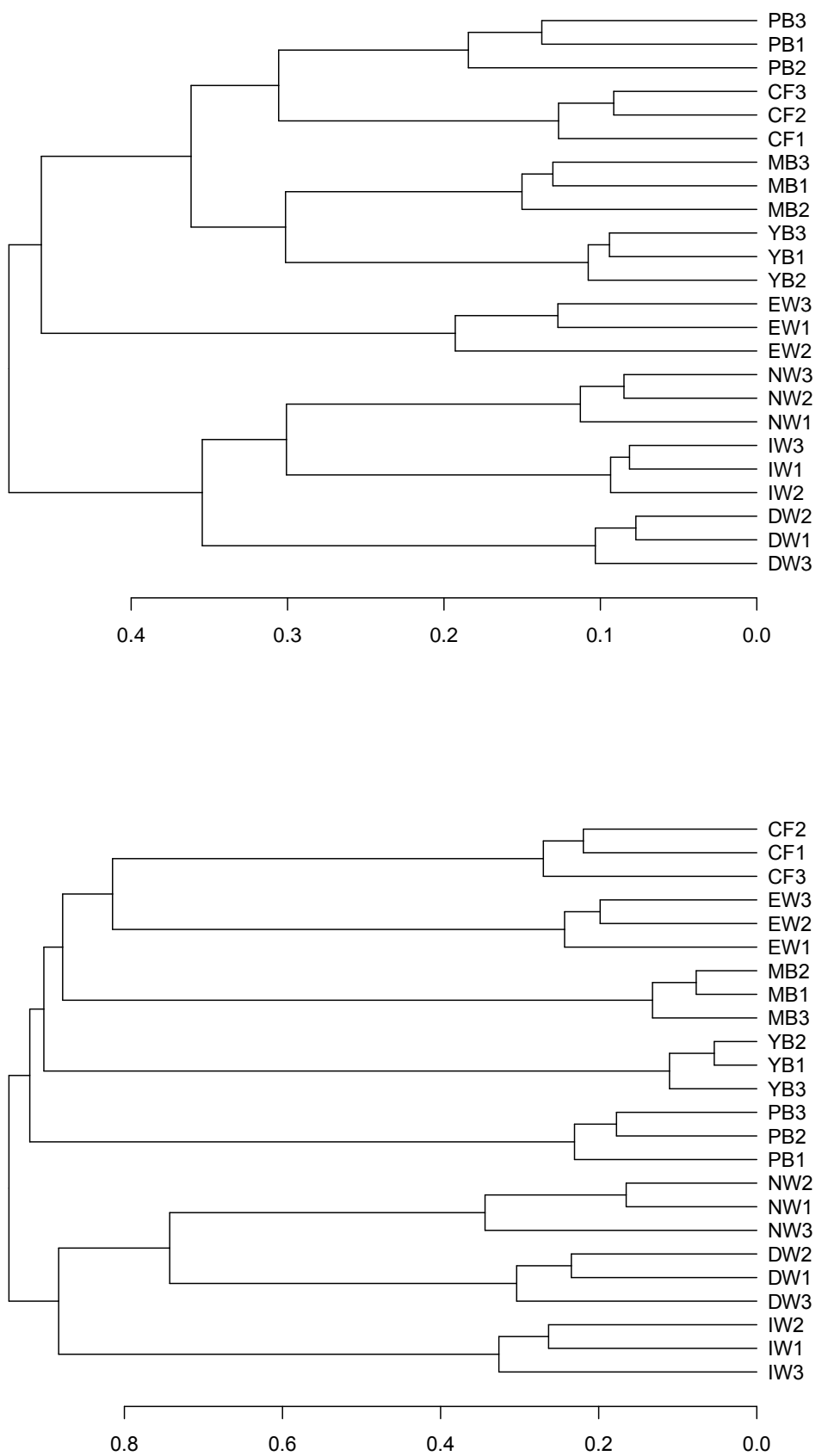